\title{
Hazel Henderson: A Pioneer in Social Indicators and Quality of Life Research
}

\section{Hazel Henderson ${ }^{1}$}

Received: 13 July 2015 / Accepted: 30 July 2015 /Published online: 16 August 2015 (C) Springer Science+Business Media Dordrecht and The International Society for Quality-of-Life Studies (ISQOLS) 2015

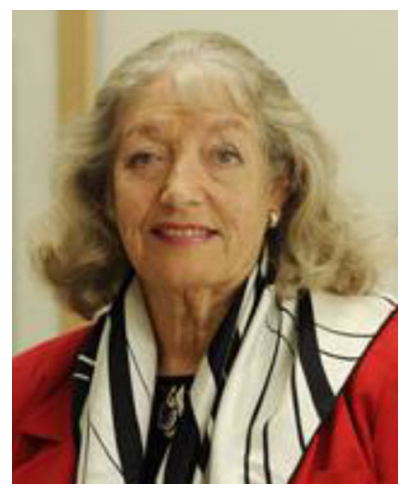

Hazel Henderson D.Sc.Hon., FRSA, is President of Ethical Markets Media, (USA and Brazil), a Certified B Corporation she founded in 2004, Editor-in-chief and Producer of its TV series. She is a futurist, evolutionary economist, worldwide syndicated columnist, consultant on sustainable development, author of the award-winning Ethical Markets: Growing the Green Economy (2006) and eight other books. She coedited, with Harlan Cleveland and Inge Kaul, The UN: Policy and Financing Alternatives, Elsevier Scientific, UK 1995 (US edition, 1996), and co-authored with Japanese Buddhist leader Daisaku Ikeda, Planetary Citizenship (2004).

Henderson's concern with GDP and other narrow cash-flow based accounting in both government and corporate balance sheets began with her co-founding of Citizens for Clean Air in New York City in 1964 as a newly naturalized US citizen. She articulated the group's concern that air pollution and other "bads" were included in

Hazel Henderson

hazel.henderson@ethicalmarkets.com

1 Ethical Markets Media, a Certified B Corporation, www.ethicalmarkets.com 
GDP undifferentiated from the "goods." Henderson invited then New York's Senator Robert Kennedy on a helicopter tour of the city to observe this air pollution's sources. Senator Kennedy in 1968 gave his famous speech critiquing GDP at the University of Kansas.

With only a high school degree from her British birthplace, Henderson published her early articles in the Harvard Business Journal (1967, 1969, 1971), the Financial Analysts Journal (1973) and the New York Times (1973), all critiquing the limitations of economics and its statistics in steering complex industrial societies. These led to her appointment to a faculty committee at Columbia University on Technology and Society and her appointments as a science advisor in Washington, DC, from 1974 until 1980. Henderson's continuous lecturing and grassroots activism on reforming GDP received global support from NGOs at the 1972 UN Summit on Environment and Development in Stockholm and the 1992 Earth Summit in Rio de Janeiro. In 2003, Henderson coorganized the first International Conference on Implementing Indicators of Sustainable Development and Quality of Life (ICONS) in Curitiba, Brazil (see "Statisticians of the World Unite!", 2003). The 700 global participating statisticians' report presented to President Ignacio Lula da Silva called for an asset budget in GDP, to lower Brazil's perceived budget deficit by properly accounting for the valuable infrastructure created by these public investments. This aided Finance Minister Dr. Paolozzi in persuading the IMF to correct its statistics. Adding asset side accounts in GDP would lower by up to half the perceived debt-to-GDP ratios of many countries, including Japan and the European Union, and re-price many of their sovereign bonds (see CSRWire "Grossly Distorted Picture").

After her election to Honorary Membership in the Club of Rome, she represented the Club on the Organizing Committed and Advisory Board of the European Commission for the influential Beyond GDP Conference in the European Parliament in 2007 (www.beyond-gdp.eu).

Her articles have appeared in over 250 journals, including (in USA) Harvard Business Review, New York Times, Christian Science Monitor; and Challenge, Mainichi (Japan), El Diario (Venezuela), World Economic Herald (China), LeMonde Diplomatique (France) and Australian Financial Review. Her books are translated into German, Spanish, Japanese, Dutch, Swedish, Korean, Portuguese, Vietnamese and Chinese. She sits on several editorial boards, including The State of the Future Report, and E/The Environmental Magazine (USA), Resurgence, Foresight, and Futures (UK).

Henderson has been Regent's Lecturer at the University of California-Santa Barbara, held the Horace Albright Chair in Conservation at the University of California-Berkeley, and advised the U.S. Office of Technology Assessment, the National Academy of Engineering and the National Science Foundation from 1974 to 1980. She holds honorary degrees from the University of San Francisco; Soka University (Tokyo); Worcester Polytechnic Institute, Massachusetts (USA); and Wilson College, Pennsylvania (USA). She is an active member of the National Press Club (Washington DC), the World Future Society (USA), and the Association for Evolutionary Economics and an Honorary Judge of the Youth Citizen Entrepreneur award and the KATERVA Global Awards for Sustainability.

Henderson is listed in Who's Who in the World, Who's Who in Business and Finance and Who's Who in Science and Technology. She shared the 1996 Global 
Citizen Award with Nobelist A. Perez Esquivel of Argentina. In 2007, she was elected a Fellow to Britain's Royal Society of Arts, founded in 1754.

In 2010, 2012, 2013 and 2014, she was honored in "Top 100 Thought Leaders in Trustworthy Business Behavior" by Trust Across America; in 2012: the Post Growth Institute (En) Rich List as a top 100 luminary inspiring global prosperity beyond economic wealth; the Award for Natural Law and Order, Maharishi University School of Management; Reuters Award for Outstanding Contribution to Development of ESG \& Investing at TBLI Europe. In 2013, she was inducted into the International Society of Sustainability Professionals Hall of Fame.

Her 2014 monograph, Mapping the Global Transition to the Solar Age, is available for free download from www.ethicalmarkets.com, forthcoming as an expanded book.

\section{Selected References}

Cleveland, H., Henderson, H., \& Kaul, I. (Eds.). (1995). The United Nations: policy and financing alternatives: innovative proposals by visionary leaders. Global Commission to Fund the United Nations.

CSRWire (2011). Grossly Distorted Picture: GDP Still Misleading Governments, Banks and Investors by Omitting Asset Accounts, by Hazel Henderson. Available at: http://csrwiretalkback.tumblr.com/post/ 2896321510/grossly-distorted-picture-gdp-still- misleading

Henderson, H. (2003). 'Statisticians of the World Unite'. Available at: http://hazelhenderson.com/2003/11/30/ statisticians-of-the-world-unite-november- 2003/

Henderson, H. (2006). Ethical markets: Growing the green economy. Vermont: Chelsea Green Publishing.

Henderson, H. (2014). Mapping the global transition to the solar age: From 'economism' to earth systems science Sustainable Business Initiative - Outside Insights. Available at: http://www.ethicalmarkets.com/ wp content/uploads/2014/02/tecpln12453- solarage-web.pdf

Henderson, H., \& Ikeda, D. (2004). Planetary Citizenship: Your Values, Beliefs, and Actions Can Shape a Sustainable World. Santa Monica: Middleway Press. 